This item was submitted to Loughborough's Research Repository by the author.

Items in Figshare are protected by copyright, with all rights reserved, unless otherwise indicated.

\title{
Effectiveness of a novel sensor selection algorithm in PEM fuel cell on-line diagnosis
}

PLEASE CITE THE PUBLISHED VERSION

https://doi.org/10.1109/TIE.2018.2795558

\section{PUBLISHER}

Institute of Electrical and Electronics Engineers

VERSION

VoR (Version of Record)

\section{PUBLISHER STATEMENT}

This work is made available according to the conditions of the Creative Commons Attribution 3.0 Unported (CC BY 3.0) licence. Full details of this licence are available at: http://creativecommons.org/licenses/by/3.0/

\section{LICENCE}

CC BY 3.0

\section{REPOSITORY RECORD}

Mao, Lei, Lisa M. Jackson, and Benjamin Davies. 2018. "Effectiveness of a Novel Sensor Selection Algorithm in PEM Fuel Cell On-line Diagnosis”. figshare. https://hdl.handle.net/2134/28232. 


\title{
Effectiveness of a novel sensor selection algorithm in PEM fuel cell on-line diagnosis
}

\author{
Lei Mao, Lisa Jackson, and Ben Davies
}

\begin{abstract}
The monitoring of engineering systems is becoming more common place because of the increasing demands on reliability and safety. Being able to diagnose a fault has been facilitated by technology developments. This has resulted in the application of methods yielding an earlier detection and thus prompter mitigation of corrective measures. The level of maturity of monitoring systems varies across domain areas, with more nascent systems in newly emerging technologies, such as fuel cells.

With the increasing complexity of systems comes the inclusion of more sensors, and for expedient on-line diagnosis utilizing the information from the most appropriate sensors is key to enabling excellent diagnostic resolution. In this paper, a novel sensor selection algorithm is proposed and its performance in Polymer Electrolyte Membrane (PEM) fuel cell on-line diagnosis is investigated. In the selection procedure, both sensor sensitivities to various failure modes and corresponding fuel cell degradation rates are considered. The optimal sensors determined from the proposed algorithm are compared with previous sensor selection techniques, where results show that the proposed algorithm can provide more efficient sensor selection results using less computational time, which makes this method better applied in practical PEM fuel cell systems for on-line diagnostic tasks.
\end{abstract}

Index Terms-PEM fuel cell, on-line diagnosis, sensor selection.

\section{NOMENCLATURE}

$\begin{array}{ll}E_{n} & \text { Reversible voltage }(\mathrm{V}) \\ F & \text { Faraday constant }(\mathrm{C} / \mathrm{mol}) \\ i & \text { Current density }\left(\mathrm{A} / \mathrm{cm}^{2}\right) \\ i_{O c} & \text { Exchange current density }\left(\mathrm{A} / \mathrm{cm}^{2}\right) \\ P_{\mathrm{H}_{2}} & \text { Hydrogen pressure (bar) } \\ P_{\mathrm{O}_{2}} & \text { Oxygen pressure (bar) }\end{array}$

Manuscript received September 28, 2017; revised December 09, 2017; accepted December 30, 2017. This work was supported by the Department of Aeronautical and Automotive Engineering, Loughborough University under Grant EP/K02101X/1 from UK Engineering and Physical Sciences Research Council (EPSRC). Experimental data discussed in this work can be found at Loughborough University Data Repository (http://lboro.figshare.com) with DOI of doi.org/10.17028/rd.lboro.5759667.v1.

Lei Mao, Lisa Jackson and Ben Davies are with the Department of Aeronautical and Automotive Engineering, Loughborough University, Loughborough,LE11,3TU,UK.(e-mail:I.mao@lboro.ac.uk; l.m.jackson@lboro.ac.uk; b.davies2@lboro.ac.uk ).

$\begin{array}{ll}R & \text { Universal gas constant }(\mathrm{J} / \mathrm{mol} . \mathrm{K}) \\ R_{\text {membrane }} & \text { Membrane resistance }\left(\Omega / \mathrm{cm}^{2}\right) \\ T & \text { Temperature }(\mathrm{K}) \\ V_{\text {cell }} & \text { Fuel cell voltage }(\mathrm{V}) \\ V_{\text {act }} & \text { Activation loss }(\mathrm{V}) \\ V_{F C} & \text { Fuel crossover loss }(\mathrm{V}) \\ V_{\text {trans }} & \text { Mass transport loss }(\mathrm{V}) \\ V_{\text {ohm }} & \text { Ohmic loss }(\mathrm{V})\end{array}$

\section{INTRODUCTION}

$T$ he degree of automation in operation and monitoring of systems has increased drastically in the last few decades, fueled by increases in computer processing capability, monitoring hardware functionality and cost, and the drive for more reliable and safer systems. More primitive monitoring systems allow for detection of faults but lack detail. Methods of modern systems use mathematical process models, estimation methods and computer intelligence to allow a greater depth of detection and diagnosis. Achieving this level of diagnostic capability requires research, especially for emerging technologies. One such emerging technology is polymer electrolyte membrane (PEM) fuel cells, utilized as an alternative power source in a range of applications from portable devices to automotive engines. Fuels cells have the potential characteristics of being zero-emission energy conversion and power generation devices, thus the drive for their inclusion to reduce the UK's carbon footprint.

Though seen within the marketplace, improvements in fuel cell reliability are still required, where application of health monitoring methods may serve to guide this improvement. A series of studies have been devoted to fuel cell fault diagnosis, including: model-based approaches, data-driven techniques, and knowledge-based methodologies. In model-based techniques, a numerical model of the system should be developed, and faults can be identified by considering the residuals between actual and model outputs [1-9]. Among these studies, fuel cell models with various levels of complexity are developed to express the fuel cell behaviour and then used for fault diagnosis. However, it should be noted that often assumptions are used in developing the model, which means the developed model can only identify specified faults and cannot be used to express fuel cell behaviour subject to different faults, although this may be experienced in practical applications. With a data-driven framework, classification of features extracted from a range of signal processing techniques 
is applied to sensor measurements to discriminate between fuel cell faults [10-21]. Most of these studies apply data-driven techniques to single sensor measurements, which may not contain enough information to discriminate performance change due to different fuel cell faults. Moreover, in studies using multiple sensor measurements $[11,21]$, the computational time is relatively expensive due to the processing of large dataset sizes. Knowledge-based techniques have incorporated prior information or expert knowledge in the analysis to better interpret the fault causes and diagnostic results, using Bayesian networks [22-23], fuzzy-rules [24], etc. In all diagnostics, to alleviate the data explosion from increasing numbers of sensors located on current systems, a balance is required between computational time and diagnostic accuracy. On this basis, it is necessary to use the fewest sensors in fuel cell diagnostic analysis that provide reliable results using minimum computational time and sensor cost.

Several studies have investigated selection of the optimal sensor set for health management of various systems, and these studies can be loosely divided into two groups. The first kind of approach defines the performance requirements to the sensors, such as diagnostic and prognostic performance, sensor reliability, electrical and physical attributes of sensors, and sensor cost. These requirements are then used to generate the optimization function, and algorithms like the genetic algorithm (GA) can be utilized to find the optimal solution [25-28]. The second approach uses a sensitivity-related analysis to evaluate sensor significance, which generates the relationship between sensors and key parameters to be monitored in the system [29-30]. However, only limited studies have been devoted in sensor selection techniques in fuel cell health management [31-32], and the performance of selected sensors in fuel cell fault diagnosis, especially on-line fault diagnosis, has not be fully investigated. Therefore, it is highly desirable to propose an effective sensor selection algorithm which can determine the optimal sensors with minimum computational cost, and provide reliable on-line diagnostic results for practical fuel cell applications.

This paper proposes a novel sensor selection algorithm based on the fuel cell failure mode effects on system degradation, and investigates the performance of these selected sensors in on-line diagnosis of a practical PEM fuel cell system. The contribution of the present study is that compared to previous sensor selection techniques (evaluating the resistance of sensors to measurement/environment noise [32]), the proposed algorithm can determine the optimal sensors in less computational time, which will be further illustrated in section 4. Therefore, the proposed algorithm is more aligned for the benefits to practical fuel cell systems, since reliability issues can be found with the selected sensors, hence the sensor selection process should be repeated without inclusion of unreliable sensors. With the proposed algorithm, the time for selecting sensors can be reduced significantly, which will not interrupt the normal operation of the fuel cell system, thus consistent monitoring can be provided with reasonable computational time for the fault diagnosis. In section 2, a PEM fuel cell model is developed and its performance is validated using the fuel cell test data. Based on the developed fuel cell model, the sensor sensitivity to fuel cell parameters is calculated in section 3. In section 4, with determined sensor sensitivities, a novel sensor selection algorithm is proposed based on the fuel cell failure mode effects on degradation, and performance of the proposed algorithm is compared to the previous sensor selection techniques in terms of computational time and performance of determined optimal sensors. Furthermore, the selected optimal sensors are applied to identify the fuel cell faults from a practical PEM fuel cell system using data-driven fault diagnostic approaches, and the results are compared to those utilizing all available sensors in section 5. From the findings, conclusions will be given in section 6 .

\section{DEVELOPMENT OF PEM FUEL CELL MODEL AND ITS PERFORMANCE VALIDATION}

In order to calculate sensor sensitivities using an experimental study, a set of experiments should be performed to obtain sensor measurements at conditions where only one fuel cell system parameter is changed, which will be time-consuming and expensive. Therefore, a numerical fuel cell model is developed and used for the sensor sensitivity calculation in this study. The developed PEM fuel cell model includes five modules as shown in Figure 1(a), and fuel cell internal behavior is expressed with space differential equations, which have been commonly used in previous studies [32-36].

In the stack voltage module, the fuel cell stack voltage can be calculated using equation (1):

$$
V_{\text {cell }}=E_{n}-V_{a c t}-V_{F C}-V_{\text {trans }}-V_{\text {ohm }}
$$

where $V_{\text {cell }}$ is the single cell voltage, $\mathrm{E}_{\mathrm{n}}$ is the reversible voltage, $V_{a c t}, V_{F C}, V_{\text {trans }}, V_{\text {ohm }}$ are the activation loss, fuel crossover loss, mass transport loss, and Ohmic loss, respectively. Each of these terms can be expressed as follows:

$$
E_{n}=-\frac{\Delta \widehat{h}-T \Delta \hat{s}}{2 F}+\frac{R T}{2 F} \ln \left(\frac{1}{P_{\mathrm{H}_{2}} P_{O_{2}}^{1 / 2}}\right)
$$

where $\Delta \hat{h}$ is the enthalpy change $(\mathrm{J} / \mathrm{mol}), \Delta \hat{S}$ is the entropy change $(\mathrm{J} / \mathrm{mol}), F$ is the Faraday constant $(\mathrm{C} / \mathrm{mol}), T$ is the fuel cell stack temperature $(\mathrm{K})$, which is obtained in stack temperature module, $P_{\mathrm{H}_{2}}$ and $P_{\mathrm{O}_{2}}$ are the hydrogen and oxygen pressure at anode and cathode (bar), respectively, which are determined in the anode mass flow and cathode mass flow modules shown in Figure 1(a).

$$
V_{\text {act }}=\frac{R T}{2 \alpha F} \ln \left(\frac{i}{i_{o c}}\right)
$$

where $R$ is the universal gas constant $(\mathrm{J} / \mathrm{mol} . \mathrm{K}), \alpha$ is the charge transfer coefficient, $i$ is the current density $\left(A / \mathrm{cm}^{2}\right), i_{o c}$ is the exchange current density $\left(A / \mathrm{cm}^{2}\right)$.

$$
V_{F C}=\frac{R T}{2 \alpha F} \ln \left(\frac{i_{n}}{i_{o c}}\right)
$$

where $i_{n}$ is the internal current density $\left(A / \mathrm{cm}^{2}\right)$.

$$
V_{\text {trans }}=m_{\text {trans }} . e^{n_{\text {trans }} \cdot i}
$$

where $m_{\text {trans }}$ and $n_{\text {trans }}$ are the mass transport loss voltage coefficients.

$$
V_{\text {ohm }}=i . R_{\text {membrane }}
$$

where $R_{\text {membrane }}$ is the membrane resistance $\left(\Omega / \mathrm{cm}^{2}\right)$, which is determined from the membrane hydration module 
shown in Figure 1(a).

Before using the developed fuel cell model to calculate sensor sensitivity, the performance of the developed fuel cell model should be validated. For this purpose, test data from two different PEM fuel cell systems are used [34-35]. Table 1 lists the PEM fuel cell parameters in these two tests. It can be seen that the two fuel cell systems have clearly different parameters, which can be used to better validate the performance of the developed model.

With the configured fuel cell model, the polarization curve for these two different PEM fuel cell systems can be obtained and compared with that from the tested fuel cell system, and the results are shown in Figures 1(b) and (c).

TABLE I

PEM Fuel CELl System PaRAmeters

\begin{tabular}{lcc}
\hline \hline \multicolumn{1}{c}{ Parameter (unit) } & Test 1[34] & Test 2 [35] \\
\hline Single cell active area $\left(\mathrm{cm}^{2}\right)$ & 232 & 25 \\
Membrane thickness $(\mu \mathrm{m})$ & 178 & 27 \\
Hydrogen pressure $(\mathrm{atm})$ & 3 & 1.6 \\
Air pressure $(\mathrm{atm})$ & 3 & 1 \\
Stack temperature $\left({ }^{\circ} \mathrm{C}\right)$ & 75 & 40 \\
\hline \hline
\end{tabular}

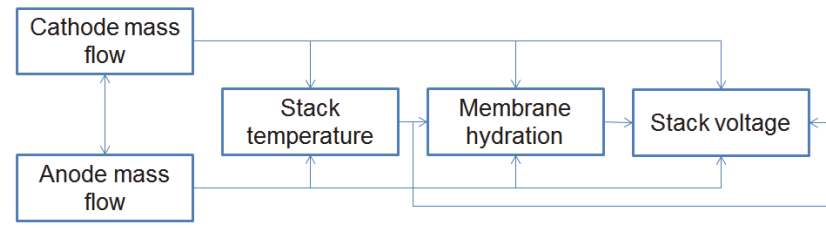

(a) Block diagram of developed fuel cell model

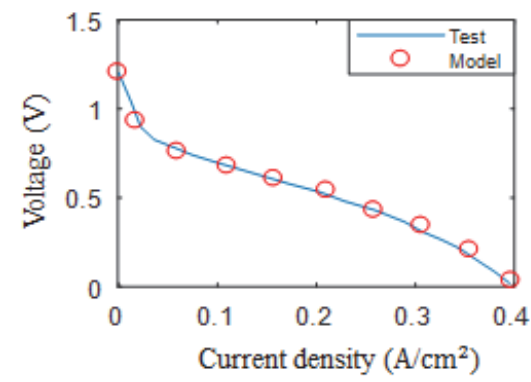

(b) Comparison of polarization curves from the model and test [34]

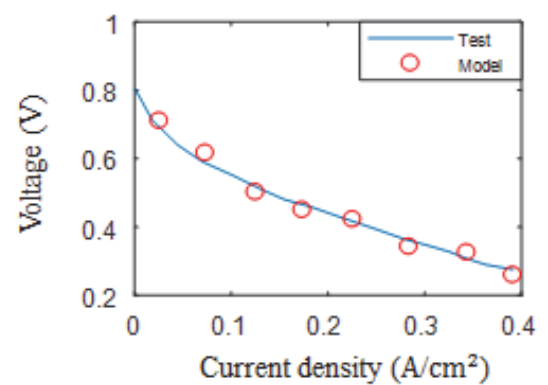

(c) Comparison of polarization curves from the model and test [35]

Fig.1 Block diagram of developed fuel cell model and its performance validation

It can be observed from Figures 1(b) and 1(c) that the polarization curves from the tested fuel cell can be simulated using the developed model with good quality, the difference of polarization curve between simulated and test data is less than $2 \%$.

\section{SENSITIVITY ANALYSIS WITH THE DEVELOPED MODEL}

With the developed fuel cell model, the sensor sensitivity to fuel cell parameters can be calculated. In this study, three fuel cell parameters are selected, including membrane resistance, electrochemical active surface area (ECSA), and liquid water in the fuel cell. The selection is based on the previous studies [36-37] where membrane and electrodes are identified as the most critical components in PEM fuel cells, and these selected fuel cell parameters can effectively represent the performance variation of these components. The sensors used in this study are those commonly used in practical fuel cell systems, such as sensors for voltage, current, inlet / outlet flow, temperature at anode and cathode sides. In the analysis, a certain change $(1 \%$ variation) is applied to the fuel cell parameters, and the variations in fuel cell responses (sensor outputs) can be obtained. From the results, sensor sensitivity to health parameters can be calculated with Eq. (7). Where $S$ represents the sensitivity value, $P_{i}$ is value of the $i^{\text {th }}$ fuel cell health parameter, $R$ is the sensor measurements, 1 and 2 represent values before and after applying the certain change, $S_{i j}$ is the $j^{\text {th }}$ sensor sensitivity for the $i^{\text {th }}$ health parameter.

It should be mentioned that the sensor sensitivity is defined as the percentage variation in sensors due to the unit change in fuel cell parameters, which can minimize the effect of different fuel cell parameters in various systems, thus can generalize the proposed approach in different fuel cell systems.

In this study, multiple fuel cell failure effect is not considered, thus in each case, only one fuel cell parameter is changed.

$$
S_{i j}=\frac{\left(R j_{2}-R_{j 1}\right) / R_{j 1}}{0.01 \times P_{i}}
$$

For better comparison, the voltage sensitivities to the selected fuel cell parameters is normalized to a unit value, and sensitivities of the other sensors to the same fuel cell parameter will be changed accordingly. By doing so, the sensitivity of each sensor to various fuel cell parameters can be compared directly, which are listed in Table 2.

TABLE II

Sensitivity of Sensors to Selected PARAmETERS

\begin{tabular}{lccc}
\hline \hline \multirow{2}{*}{ Sensor output } & \multicolumn{2}{c}{ Health Parameter } \\
\cline { 2 - 4 } & $\begin{array}{c}\text { Membrane } \\
\text { resistance }\end{array}$ & $\begin{array}{c}\text { Cell active } \\
\text { area }\end{array}$ & $\begin{array}{c}\text { Liquid water } \\
\text { inside cell }\end{array}$ \\
\hline Cell voltage & 1 & 1 & 1 \\
Stack temperature & 0.035 & 0.013 & 3.5 \\
Cathode inlet flow & 0.371 & 0.335 & 68.55 \\
Anode outlet flow & 0.268 & 0.322 & 65.07 \\
Cathode outlet flow & 0.314 & 0.313 & 826.1 \\
Inlet water temp & 0.00061 & 0.003 & 0.049 \\
Outlet water temp & 0.00061 & 0.00046 & 0 \\
\hline \hline
\end{tabular}


It should be mentioned that several sensors, including anode inlet flow, compressor temperature, and coolant inlet flow, have zero sensitivities to the fuel cell parameters, which means they will not be affected with corresponding fuel cell failure modes Therefore, these sensors are not listed in Table 2 and will not be selected in the optimal sensor set in the following analysis.

\section{PROPOSED SENSOR SELECTION ALGORITHM}

In this section, a novel sensor selection algorithm will be proposed based on the above sensitivity analysis results and fuel cell failure mode effects. Moreover, its performance will be compared to previous sensor selection techniques in terms of selected sensors and computational time for the selection.

\subsection{Proposed sensor selection algorithm}

It can be seen from Table 2 that sensors may show various sensitivities to different fuel cell parameters, which will make sensor selection analysis more difficult in practical fuel cell systems, since information about fuel cell failure modes cannot be accessed in advance. On this basis, the failure mode weighting based selection method is proposed based on the fact that different failure modes may cause various levels of system performance degradation, thus in cases where prior knowledge of fuel cell faults is unavailable, sensors should be selected based on the severity of failure modes to the system performance, i.e. a sensor has higher probability to be selected if it is more sensitive to the failure mode causing faster system performance degradation, this can be expressed as

$$
O S_{k}=\sum_{i}^{n} D_{i} / R_{i k}
$$

where $O S_{k}$ is overall performance of the $\mathrm{k}^{\text {th }}$ sensor, $D_{i}$ is the system degradation rate due to the $i^{\text {th }}$ system failure mode, which is listed in Table 3 from the prior knowledge through experimental or numerical analysis [37-38], $R_{i k}$ is rank of the $k^{\text {th }}$ sensor sensitivity to the $i^{\text {th }}$ failure mode, this can be obtained from the sensitivity analysis shown in Table $2, \mathrm{n}$ is the total number of considered system failure modes.

With results from Eq. (8), available sensors can be ranked based on the corresponding overall performance, then the optimal sensor set can be determined by evaluating performance of the sensor set with various sizes (the size is increased gradually based on the sensor overall performance, which is listed in Table 4).

TABLE III

Degradation Rates of Various Fuel Cell Failure Modes

\begin{tabular}{cc}
\hline \hline Failure mode & Degradation rate $(\mathrm{V} / \mathrm{h})$ \\
\hline Flooding & 0.39 \\
Membrane drying out & 0.25 \\
Reduction of cell active area & 0.025 \\
\hline
\end{tabular}

TABLE IV

SENSOR SETS Used IN THE ANALYSIS

\begin{tabular}{ll}
\hline \hline $\begin{array}{c}\text { Sensor } \\
\text { set }\end{array}$ & Sensors included \\
\hline & Cathode inlet flow \\
2 & Cathode inlet flow, Cathode outlet flow
\end{tabular}
3
Cathode inlet flow, Cathode outlet flow, Anode outlet flow;
Cathode inlet flow, Cathode outlet flow, Anode outlet flow, Stack temperature;
Cathode inlet flow, Cathode outlet flow, Anode outlet flow, Stack temperature, Water inlet temperature;

In the current study, Adaptive Neuro-Fuzzy Inference System (ANFIS) is selected to evaluate the performance of various sensor sets shown in Table 4, as it has already been proved to be effective in predicting fuel cell performance [41-43]. Moreover, the test data from [40] is used to analyze the performance of various sensor sets in expressing the fuel cell behavior.

ANFIS structure is shown in Figure 2. Fuzzification is applied to the inputs based on the membership functions, and the rules can be generated and normalized to process the outputs from the fuzzification layer, before calculating the ANFIS outputs, defuzzification layer should be applied. These activities can be written with the following equations, and more details about ANFIS can be found in previous studies [41-43].

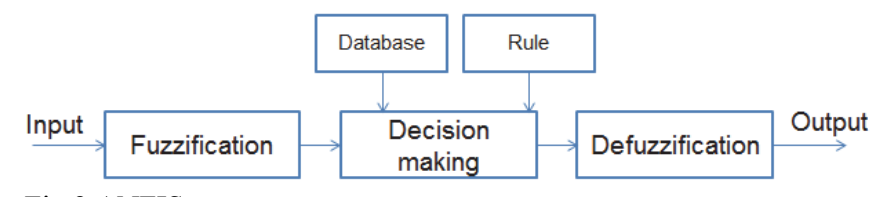

Fig.2 ANFIS structure

Fuzzification:

$$
y_{i}^{1}=\mu_{A_{i}^{j}}\left(x_{i}^{1}\right)=\frac{1}{1+\left|\frac{x_{i}^{1}-c_{i}}{a_{i}}\right|^{2 b_{i}}}
$$

where $\mu_{A_{i}^{j}}$ is the fuzzy rule associated with $i^{\text {th }}$ input and $j^{\text {th }}$ fuzzy rule, $y_{i}^{1}$ is the $i^{\text {th }}$ output at layer $1, a_{i}, b_{i}$ and $c_{i}$ are the parameters in the membership function, which will be adjusted during the training phase.

Decision making unit:

$$
\begin{aligned}
& y_{i}^{2}=\omega_{i}=\prod_{i} \mu_{A_{i}^{j}}\left(x_{i}^{1}\right) \\
& y_{i}^{3}=\overline{\omega_{l}}=\frac{\omega_{i}}{\sum_{1}^{i} \omega_{i}}
\end{aligned}
$$

where $\omega_{i}$ is the firing strength of the rule.

Defuzzification:

$$
\begin{array}{cc} 
& y_{i}^{4}=\overline{\omega_{l}} f_{i}=\bar{\omega}_{\imath}\left(c_{1}^{j} x_{1}+c_{2}^{j} x_{2}+c_{3}^{j}\right) \\
\text { Output: } & y_{i}^{5}=\sum_{i} \bar{\omega}_{l} f_{i}
\end{array}
$$

In this analysis, the inputs of the ANFIS are the measurements from the selected sensor set, and the output is the fuel cell voltage. The first $2 / 3$ rds of the data samples are used to train the ANFIS system, while the last $1 / 3$ rd of the data samples are used to validate the performance of selected sensors. Table 5 list the mean prediction error and computation time for sensor sets in Table 4.

TABLE V

MEAN PREDICTION ERROR AND COMPUTATIONAL TIME FOR VARIOUS SENSOR SETS

\begin{tabular}{ccc}
\hline \hline $\begin{array}{c}\text { Sensor } \\
\text { set }\end{array}$ & $\begin{array}{c}\text { Mean prediction error } \\
(\mathrm{V})\end{array}$ & $\begin{array}{c}\text { Computational } \\
\text { time }(\mathrm{s})\end{array}$ \\
\hline 1 & 0.061 & 10.8 \\
2 & 0.052 & 77.6
\end{tabular}




\begin{tabular}{lrr}
3 & 0.040 & 99.6 \\
4 & 0.014 & 162.1 \\
5 & 0.014 & 522.3 \\
\hline
\end{tabular}

From Table 5, it can be seen that with increase of sensor number, the mean prediction error can be reduced effectively, but the computational time is increased. Therefore, by considering both the selected sensor set performance and computation time, optimal sensor set containing four sensors (Stack temperature, Water inlet temperature, Cathode outlet flow, Cathode inlet flow) is selected for the following fuel cell fault diagnosis, as the prediction performance cannot be improved with further increase of sensor numbers, while computational time will be increased significantly.

\subsection{Comparison study with previous sensor selection techniques}

In this study, two sensor selection techniques are used to validate the optimal sensors determined using the proposed algorithm, including exhaustive brute force searching and sensor noise resistance-based selection techniques mentioned in [32].

With the brute force searching method, all possible sensor combinations are searched to find the optimal sensors providing the best performance, which can be evaluated using the defined objective function written as the following equation.

$$
f(x)=\frac{1}{N} \sum_{i}^{N} a b s\left(v_{i}-p_{i}\right)
$$

where $v_{i}$ is the actual fuel cell voltage, and $p_{i}$ is the corresponding prediction, $N$ is the number of sample points in the analysis.

ANFIS is used herein to evaluate the performance of different sensor combinations, and the optimal sensors can be determined by minimizing Eq.(14) using the smallest size of sensor set, which is listed in Table 6.

TABLE VI

SELECTED SENSORS FRom EXHAUSTIVE SEARCHING TECHNIQUe

\begin{tabular}{lc}
\multicolumn{1}{c}{ Sensor set } & Objective function value \\
\hline \hline $\begin{array}{l}\text { Anode outlet temperature, Cathode outlet flow, } \\
\text { Cathode inlet flow }\end{array}$ & 0.0132 \\
$\begin{array}{l}\text { Cathode inlet temperature, Cathode outlet flow, } \\
\text { Cathode inlet flow } \\
\text { Cathode outlet temperature, Cathode outlet flow, }\end{array}$ & 0.0135 \\
$\begin{array}{l}\text { Cathode inlet flow } \\
\text { Anode inlet temperature, Cathode outlet flow, } \\
\text { Cathode inlet flow }\end{array}$ & 0.0135 \\
\hline \hline
\end{tabular}

It can be found from Table 6 that the difference in the four selected sensor sets is that the thermometer is placed at different locations in these sensor sets. This is reasonable as in practical PEM fuel cell systems, it is difficult to measure the fuel cell temperature directly, and the thermometers are usually placed at the inlet/outlet of anode and cathode sides.

The other technique included in the analysis is the sensor noise resistance-based selection method used in previous study [32], which considers sensor noise resistance with the following equation.

$$
\{\delta P\}=\left(S^{T} S\right)^{-1} S^{T}\{\delta R\}=G\{\delta R\}
$$

where $S$ is the sensitivity matrix, $\{\delta R\}$ is the variation in sensor measurements, and $\{\delta P\}$ is the perturbations in fuel cell parameters.

The evaluation of noise resistance of these sensors can be performed using Eq. (15). A set of (say n sets) response errors are generated randomly to express the measurement noise, ( $\pm 2 \%$ of the sensor measurements is used herein). With the subset of gain matrix $G$, the corresponding fuel cell parameter errors ( $\mathrm{n}$ sets) can be calculated using Eq. (15). From the fuel cell parameter errors, a statistical analysis is performed. For example, the error for a particular parameter $P_{i}$ is denoted as $\left\{\delta P_{i}\right\}$, which consists of n scalar components, the mean value $\mu_{i}$ and standard deviation $\sigma_{i}$ are calculated from $\left\{\delta P_{i}\right\}$. Theoretically speaking, $\mu_{i}$ should be close to zero, thus the parameter error can be expressed using $\sigma_{i}$. The index $S D$ can be defined by including $\sigma_{i}$ from errors of all the fuel cell parameters

$$
S D=\left[\begin{array}{llll}
\sigma_{1} & \sigma_{2} & \ldots & \sigma_{p}
\end{array}\right]
$$

where $\mathrm{p}$ represents the number of fuel cell parameters, and the overall error can be used to express the noise resistance of the selected sensor set $(N R)$,

$$
N R=\mu_{S D}+\sigma_{S D} / \mu_{S D}
$$

With this method, three sensors are determined as optimal sensors, including stack temperature, cathode outlet flow and cathode inlet flow [32].

Table 7 lists the comparison results between the proposed algorithm and the other two sensor selection techniques, in terms of computational time for the determination of selected

\begin{tabular}{|c|c|c|c|}
\hline & $\begin{array}{l}\text { Selected } \\
\text { sensors }\end{array}$ & $\begin{array}{c}\text { Mean } \\
\text { prediction error (V) }\end{array}$ & $\begin{array}{l}\text { Time } \\
(\mathrm{min})\end{array}$ \\
\hline Proposed algorithm & $\begin{array}{l}\text { Stack temperature, } \\
\text { Water inlet } \\
\text { temperature, } \\
\text { Cathode outlet flow, } \\
\text { Cathode inlet flow }\end{array}$ & 0.014 & 11 \\
\hline $\begin{array}{l}\text { Exhaustive } \\
\text { searching }\end{array}$ & $\begin{array}{l}\text { Stack temperature, } \\
\text { Cathode outlet flow, } \\
\text { Cathode inlet flow }\end{array}$ & 0.0132 & $>8530$ \\
\hline $\begin{array}{l}\text { Noise-resistance } \\
\text { based }\end{array}$ & $\begin{array}{l}\text { Stack temperature, } \\
\text { Cathode outlet flow, } \\
\text { Cathode inlet flow }\end{array}$ & 0.0132 & 35 \\
\hline
\end{tabular}
sensors, number of selected sensors and their performance.

TABLE VII

COMPARISON RESULTS OF THREE SENSOR SELECTION ALGORITHMS

It can be found from Table 7 that compared with the brute force searching method and sensor noise resistance based method, the proposed algorithm provides one more sensor in the optimal sensor set (water inlet temperature), but this will not affect the performance of expressing fuel cell behavior significantly. Moreover, the proposed algorithm uses minimum computational time for the optimal sensor determination, which will be beneficial in practical application, as computational time is usually critical for on-line diagnostic tasks.

It should be noted that once the optimal sensors are 
determined, the on-line fault diagnosis can be performed, which will be further illustrated in the following section. Moreover, in cases where reliability of selected sensors is reduced during the fuel cell operation, i.e. selected sensor start providing misleading readings, the proposed sensor selection technique should be performed again to update the optimal sensors. As minimum computational time is involved in the selection analysis, the proposed approach can minimize the interruption time of the fuel cell normal operation for selecting the optimal sensors.

\section{EFFECTIVENESS OF PROPOSED ALGORITHM IN PEM FUEL CELL ON-LINE DIAGNOSIS}

In this section, the performance of optimal sensor set in identifying fuel cell faults will be studied using test data from a PEM fuel cell system. In the diagnostic process, several data-driven approaches are applied to the measurements from the optimal sensor set, including kernel principal component analysis (KPCA), wavelet packet transform (WPT) and singular value decomposition (SVD), which will be described in the following section. Moreover, the results of fuel cell fault diagnostics using optimal sensor set will be compared to those with involvement of all the sensors to demonstrate the effectiveness of optimal sensors in fuel cell fault diagnosis.

\subsection{Description of sensor measurements}

As described before, test data from a PEM fuel cell system is used to study the performance of optimal sensors. In this study, a test rig with capability of $800 \mathrm{~W}$ is used to provide the PEM fuel cell test data, which contains a fuel cell stack, air and hydrogen supply systems, cooling system, and TDI power load bank manufactured by Astrodyne TDI to consume the energy produced from the stack. Figure 3 depicts the tested PEM fuel cell system and Table 8 lists the sensors used in the PEM fuel cell system. It should be mentioned that the commonly used sensors in fuel cell systems are installed in the current PEM fuel cell systems, including stack voltage, load current, pressure, stack temperature, flow rates and pressures at anode and cathode sides.

TABLE VIII

SENSOR MeAsurements From The EC Fuel CELL System

\begin{tabular}{cl}
\hline \hline Sensor (unit) & \multicolumn{1}{c}{ Sensor (unit) } \\
\hline Stack voltage (V) & \multicolumn{1}{c}{ Load Current (A) } \\
Anode reactant flow (SPLM) & Anode inlet pressure (bars) \\
Anode outlet pressure (bars) & Cathode inlet pressure (bars) \\
Cathode outlet pressure (bars) & Cathode air inlet flow (SPLM) \\
Stack temperature $\left({ }^{\circ} \mathrm{C}\right.$ ) & Anode relative humidity \\
Cathode relative humidity & \\
& \\
\hline \hline
\end{tabular}

In this study, the fuel cell electrode flooding is used to study the performance of selected sensors. The reason is that from previous studies [38-39], flooding can cause the fastest performance degradation in the PEM fuel cell system, and with prompt mitigation strategies, the fuel cell performance can be recovered from the flooding.

In the test, the PEM fuel cell is firstly operated at nominal conditions (listed in Table 9) for a certain duration, then the current density is increased to produce more water to cause electrode flooding, this procedure is repeated three times. Figure 4 shows the current density used in the test and corresponding fuel cell stack voltage.

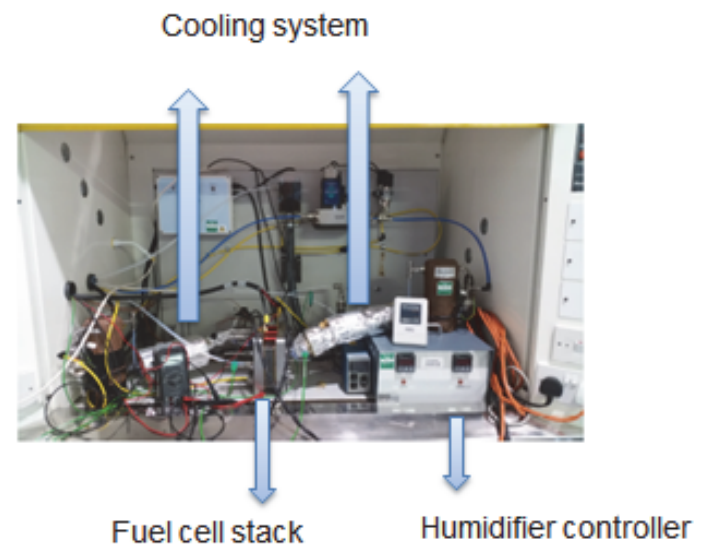

Fig.3 Tested PEM fuel cell system

TABLE IX

Nominal PEM Fuel Cell Operating Condition

Parameter

Value

$\begin{array}{ll}\text { Reactant stoichiometry } & 1 / 3 @ \text { nominal (an/ca) } \\ \text { Voltage range } & 0.8-0.83 \mathrm{~V} \\ \text { Stack temperature } & 54-56^{\circ} \mathrm{C} \\ \end{array}$
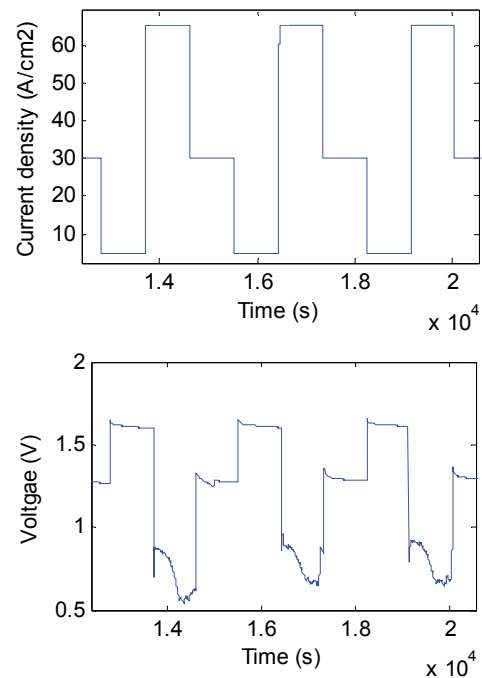

Fig.4 Current density and stack voltage during the test

It can be seen from Figure 4 that after the increase of current density, the stack voltage starts to decrease gradually, indicating the accumulation of liquid water and electrode flooding, while with lower current density, the stack voltage is increased and stay as a constant value, this means the fuel cell performance can be recovered effectively using proper mitigation strategies (reducing the current density herein). 


\subsection{Data-driven diagnostic approaches}

A data-driven diagnostic framework depicted in Figure 5 is used to identify the fuel cell faults using optimal sensors, These approaches will be described briefly herein, and more details can be found in previous studies [14, 44-48]. It should be mentioned that the diagnostic approaches used herein have been widely used in several systems for fault diagnosis, and their performance has been deeply investigated. Therefore, the selection of these commonly used diagnostic approaches in this study can better illustrate the effectiveness of selected sensors in PEM fuel cell fault diagnosis.

\begin{tabular}{|c|}
\hline $\begin{array}{c}\text { Reduction of dataset dimension to four principal } \\
\text { directions using KPCA }\end{array}$ \\
\hline $\begin{array}{c}\text { Extracting wavelet coefficients using WPT over } \\
\text { three levels }\end{array}$ \\
\hline Generation of normalized energy with wavelet \\
coefficients
\end{tabular}

Fig.5 Flowchart of data-driven fault diagnostic framework

The general idea of KPCA is a non-linear mapping of the original dataset to a higher-dimension space, where they vary linearly. KPCA firstly constructs and modifies the kernel matrix using the original dataset using the following equations.

$$
K_{i, j}=\kappa\left(x_{i}, x_{j}\right)
$$

where $K$ is the constructed kernel matrix, $\kappa$ is the kernel function, $\kappa\left(x_{i}, x_{j}\right)=\phi\left(x_{i}\right)^{T} \phi\left(x_{j}\right), \phi$ creates linearly independent variables from the original data $x_{i}$ and $x_{j}$;

$$
\widetilde{K}=K-1_{n} K-K 1_{n}+1_{n} K 1_{n}
$$

where $1_{n}$ is the $\mathrm{n} \times \mathrm{n}$ matrix where all elements take the value of $1 / \mathrm{n}, \widetilde{K}$ is the modified kernel matrix;

With the modified kernel matrix, the highest $L$ eigenvalues and corresponding eigenvector $\left(a_{1}, a_{2}, \ldots, a_{L}\right)$ can be calculated, and the original data can be projected to the new direction using:

$$
z_{l}=\sum_{i=1}^{n} a_{l n} \kappa\left(x_{i}, x\right)
$$

where $z_{l}$ is the 1 th element of the projected vector ( $l \in$ $1,2, \ldots L), a_{l n}$ is the corresponding value in the above calculated eigenvectors .

With the procedure, the high dimension dataset can be reduced significantly without losing useful information, which can be evaluated using equation (21),

$$
\frac{\sum_{i=1}^{L} \lambda_{i}}{\sum_{i=1}^{n} \lambda_{i}}<T
$$

where $\lambda_{i}$ is the $i^{\text {th }}$ principal component, $n$ is the number of total principal component, and $L$ is the selected number of principal components (with the selected principal components, useful information will not be lost), $T$ is the threshold value ( 0.95 is selected in this case based on previous studies [18-19]).
Based on Eq. (21), four principal components are selected herein to express the information in the original dataset with size of 22, and in the following analysis, the fault diagnosis will be performed at these principal directions.

WPT is then applied to extract the features from the reduced dataset, in which the dataset is passed through filters to get low-pass (approximation) and high-pass results (detail). Compared to the conventional wavelet transform, WPT can provide more wavelet coefficients as both approximation and detail will be filtered to get the next level approximation and detail, respectively. Based on the wavelet coefficient, normalized energy is generated using the following equation.

$$
E^{p}=\frac{1}{N_{p}} \sum_{j . k}\left|C_{j, k}^{p}\right|^{2}
$$

where $E^{p}$ is the normalized energy for specific wavelet packet $p, N_{p}$ is the number of coefficients in wavelet packet $p$, and $C_{j, k}^{p}$ is the coefficient in wavelet packet $p$.

Finally SVD is used to select the features (normalized energy herein) for the fuel cell fault identification, as multiple features can be generated from the WPT. The principle of SVD is to identify and sort the features based on the contained information, and in this study, the two features contained the most information are selected and used in the analysis.

\subsection{Diagnostic performance with all the sensors}

Before evaluating the performance of optimal sensors, the diagnostic performance of all sensors will be studied in this section.

It should be mentioned that in the analysis, only the test data at higher current density is selected, which corresponds to the fuel cell performance due to the electrode flooding. Moreover, the test data is divided into several categories, including normal state without voltage drop, transition state with voltage drop less than $3 \%$, and flooding state with more than $3 \%$ voltage drop. With definition of these states, the performance of selected sensors in identifying fuel cell faults with different levels can be better illustrated.

Figure 6 depicts the diagnostic results with all sensors using the described diagnostic procedure. It can be seen that with all the sensors, clearly boundaries between different fuel cell states (normal, transition and flooding) cannot be found at the $1^{\text {st }}$ principal direction, especially for transition and flooding states. Moreover, compared to the results in the $1^{\text {st }}$ principal direction, more misleading results can be observed in the $2^{\text {nd }}$ principal direction, where features from all three states are close and cannot be discriminated. This indicates that with all available sensors, the early stage fuel cell flooding cannot be identified, thus mitigation strategies cannot be applied promptly to recover fuel cell performance.

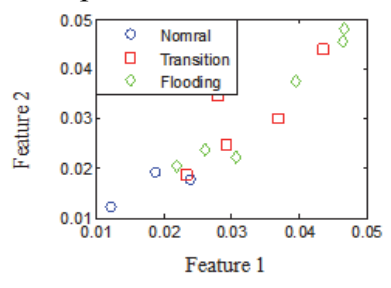

(a) $1^{\text {st }}$ principal direction

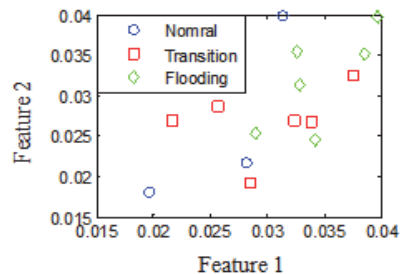

(b) $2^{\text {nd }}$ principal direction 
Fig. 6 Diagnostic results with all the sensors

\subsection{Diagnostic performance of optimal sensor set}

In this section, the diagnostic procedure described before will be applied to the measurements from the optimal sensor set. It should be mentioned that the same diagnostic process is used except that the KPCA will only be applied to the optimal sensors measurements.

Figure 7 depicts the diagnostic results of the first two principal directions using optimal sensor set with 4 sensors, which are determined in section 4.1. Compared to results using all the sensors (shown in Figure 6), it can be seen that in all principal directions, the different fuel cell states can be clearly separated using selected sensors. Moreover, the normal state can be clearly discriminated from the transition and flooding states, indicating that with selected sensors, even the early stage performance degradation can be identified, which can be beneficial in practical applications to apply mitigation strategies for performance recovery.
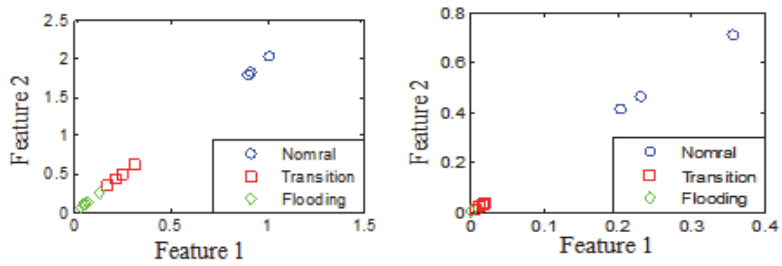

(a) $1^{\text {st }}$ principal direction (b) $2^{\text {nd }}$ principal direction Figure 7 Diagnostic results with selected sensors

Tables 10 and 11 further compare the diagnostic performance using all the sensors and optimal sensors with a confusion matrix. It can be seen that with optimal sensor set, different fuel cell states can be discriminated with good quality. Moreover, compared to the computational time for diagnostic analysis using all the sensors (10min), the computational time of diagnostic analysis using selected sensor is reduced significantly $(2 \mathrm{~min})$, this can better meet the requirement of on-line monitoring tasks for practical fuel cell systems.

TABLE $X$

CONFUSION MATRIX WITH ALL AVAILABLE SENSORS (SHOWN IN FIGURE 6) Predicted

\begin{tabular}{lllll} 
& & Normal & Transition & Flooding \\
& & & & \\
\hline \multirow{3}{*}{ Actual } & Normal & $83.3 \%$ & 0 & $16.7 \%$ \\
& Transition & $33.3 \%$ & $50 \%$ & $16.7 \%$ \\
& Flooding & $8.3 \%$ & $33.3 \%$ & $58.4 \%$ \\
& & & \\
\hline \hline
\end{tabular}

TABLE XI

CONFUSION MATRIX WITH SELECTED SENSORS (SHOWN IN FIGURE 7) Predicted

\begin{tabular}{llccc} 
& & & & \\
\cline { 3 - 5 } Actual & & & & \\
\hline \multirow{3}{*}{ Normal } & Transition & Flooding \\
& Normal & $100 \%$ & 0 & 0 \\
& Transition & 0 & $100 \%$ & 0 \\
& Flooding & 0 & 0 & $100 \%$ \\
\hline \hline
\end{tabular}

\section{CONCLUSION}

In the paper, a novel sensor selection algorithm is proposed based on the sensor sensitivities and fuel cell failure mode effects, and the performance of selected sensors in PEM fuel cell on-line diagnosis is further investigated.

In the analysis, sensitivity analysis is performed with the developed PEM fuel cell model. From the results, the available sensors can be ranked, and weights can be assigned to the sensors based on the failure mode effects on the fuel cell degradation. With weighted sensors and corresponding sensitivities, optimal sensors can be determined by evaluating performance of several candidate sensor sets. The performance of proposed algorithm is then compared with the previous sensor selection techniques, including exhaustive brute force searching and sensor noise-resistance based selection technique. Results demonstrate that the proposed algorithm can provide the optimal sensors with the minimum computational cost, thus it can be used in practical application for the fast decision of the optimal sensors.

The diagnostic performance of optimal sensors is further studied using test data from a PEM fuel cell system. With data-driven approaches including KPCA, wavelet packet transform, and SVD, different levels in fuel cell flooding can be successfully identified using the optimal sensors. Compared to diagnostic results using all the available sensors, diagnostic results using optimal sensors provides less misclassifications of fuel cell state with less computational time, this can be better used in practical fuel cell systems to provide on-line health monitoring service.

\section{REFERENCES}

[1] A. Forrai, H. Funato, Y. Yanagita, Y. Kato, "Fuel-cell parameter estimation and diagnostics, "IEEE Transactions on Energy Conversion, vol.20, pp.668-675, 2005.

[2] N. Fouquet, C. Doulet, C. Nouillant, G.D. Tanguy, B.O. Bouamama, "Model based PEM fuel cell state-of-health monitoring via ac impedance measurements, " Journal of Power Sources, vol.159, pp.905-913, 2006.

[3] A. Ingimundarson, A.G. Stefanopoulou, D.A. McKay, "Model-based detection of hydrogen leaks in a fuel cell stack, " IEEE Transactions on Control Systems Technology, vol.16, pp.1004-1012, 2008.

[4] J.H. Ohs, U. Sauter, S. Maass, D, Stolten, "Modeling hydrogen starvation conditions in proton exchange membrane fuel cells, "Journal of Power Sources, vol.196, pp.255-263, 2011.

[5] M.A. Rubio, A. Urquia, S. Dormido, "Diagnosis of performance degradation phenomenon in PEM fuel cells," International Journal of Hydrogen Energy, vol.35, pp.2586-2590, 2010.

[6] A. Zeller, O. Rallieres, J. Regnier, C. Turpin, "Diagnosis of a hydrogen/air fuel cell by a statistical model-based method," Vehicle Power and Propulsion Conference (VPPC), Lille, France 2010.

[7] M.M. Kamal, D. Yu, "Model-based fault detection for proton exchange membrane fuel cell systems," International Journal of Engineering, Science and Technology, vol.3, pp.1-15, 2011.

[8] A. Mohammadi, A. Djerdir, D. Bouquain, B. Bouriot, D. Khaburi, "Fault sensitive modeling and diagnosis of PEM fuel cell for automotive applications," Transportation Electrification Conference and Expo (ITEC), Detroit, USA, 2013.

[9] R. Petrone, Z. Zheng, D. Hissel, M.C. Pera, C. Pianese, M. Sorrentino, M. Becherif, N. Yousfi-Steiner, "A review on model-based diagnosis methodologies for PEMFCs," International Journal of Hydrogen Energy, vol.38, pp.7077-7091, 2013.

[10] A. Narjiss, D. Depernet, D. Candusso, F. Custin, D. Hissel, "Online diagnosis of PEM fuel cell, "13th Power Electronics and Motion Control Conference, Poznan, Poland 2008. 
[11] B. Legros, P.X. Thivel, Y. Bultel, M. Boinet, R.P. Nogueira, “Accoustic emission: towards a real-time diagnosis technique for proton exchange membrane fuel cell operation, "Journal of Power Sources, vol.195, pp.8124-8133, 2010.

[12] L. Placca, R. Kouta, D. Candusso, J.F. Blachot, W. Charon, "Analysis of PEM fuel cell experimental data using principle component analysis and multi linear regression, " International Journal of Hydrogen Energy, vol.35, pp.4582-4591, 2010.

[13] Z. Zheng, R. Petrone, M.C. Pera, D. Hissel, M. Becherif, C. Pianese, N.Y. Steiner, M. Sorrentino, "A review on non-model based diagnosis methodologies for PEM fuel cell stacks and systems, " International Journal of Hydrogen Energy, vol.38, pp.8914-8926, 2013.

[14] N.Y. Steiner, D. Hissel, P. Mocoteguy, D. Candusso, "Non intrusive diagnosis of polymer electrolyte fuel cells by wavelet packet transform," International Journal of Hydrogen Energy, vol.36, pp.740-746, 2011.

[15] L. Zhongliang, R. Outbib, S. Giurgea, D. Hissel, Y. Li, "Fault detection and isolation for polymer electrolyte membrane fuel cell systems by analysing cell voltage generated space," Applied Energy, vol.148, pp. 260-272, 2015.

[16] J. Chen, B. Zhou, "Diagnosis of PEM fuel cell stack dynamic behaviours," Journal of Power Sources, vol.177, pp.83-95, 2008.

[17] M. Bonvini, M.D. Sohn, J. Granderson, M. Wetter, M.A. Piette. "Robust on-line fault detection diagnosis for HVAC components based on nonlinear state estimation techniques," Applied Energy, vol.124, pp.156-166, 2014.

[18] M. Kim, N. Jung, K. Eorn, S.J. Yoo, J.Y. Kim, J.H. Jang, H.J. Kim, B.K. Hong, E. Cho, "Effects of anode flooding on the performance degradation of polymer electrolyte membrane fuel cells, ” Journal of Power Sources, vol.266, pp.1332-340, 2014.

[19] E. Pahon, N.Y. Steiner, S. Jemei, D. Hissel, P. Mocoteguy, "A signal-based method for fast PEMFC diagnosis, " Applied Energy, vol.165, pp.748-758, 2016.

[20] J.G. Kim, S. Mukherjee, A. Bates, B. Zickel, S. Park, B.R. Son, J.S. Choi, O. Kwon, D.H. Lee, H.Y. Chung, "Autocorrelation standard deviation and root mean square frequency analysis of polymer electrolyte membrane fuel cell to monitor for hydrogen and air undersupply," Journal of Power Sources, vol.300, pp.164-174, 2015.

[21] L. Mao, L.M. Jackson, S.J. Dunnett, "Fault diagnosis of practical polymer electrolyte membrane (PEM) fuel cell system with data-driven approaches," Fuel Cells, vol.17, pp.247-258, 2017.

[22] L.A.M. Riascos, M.G. Simoes, P.E. Miyagi, “A Bayesian network fault diagnostic system for proton exchange membrane fuel cells, ” Journal of Power Sources, vol.165, pp.267-278, 2007.

[23] L.A.M Riascos, M.G. Simoes, P.E. Miyagi, "On-line fault diagnostic system for proton exchange membrane fuel cells," Journal of Power Sources, vol.175, pp.419-429, 2008.

[24] B. Davies, L. Jackson, S. Dunnett, "Expert diagnosis of polymer electrolyte fuel cells," International Journal of Hydrogen Energy, vol. 42, pp. 11724-11734, 2017.

[25] T.S. Sowers, G. Kopasakis, D.L. Simon, "Application of the systematic sensor selection strategy for turbofan engine diagnostics," Turbo Expo 2008 Gas Turbine Technical Congress and Exposition, Berlin, Germany 2008.

[26] D.L. Simon, S. Garg, "A systematic approach to sensor selection for aircraft engine health estimation," 19th ISABE conference, Montreal, Canada 2009

[27] Y. Shuming, Q. Jing, L. Guanjun, "Sensor optimization selection model based on testability constraint," Chinese Journal of Aeronautics, vol.25, pp.262-268, 2012.

[28] A.M. William, K. George, M.S. Louis, S.S. Thomas, C. Amy, "Sensor Selection and Optimization for Health Assessment of Aerospace Systems," Journal of Aerospace Computing, Information, and Communication, vol.5, pp.16-34, 2008 .

[29] P.M. Szecowka, A. Szczurek, M.A. Mazurowski, B.W. Licznerski, F. Pichler, "Neural network sensitivity analysis applied for the reduction of the sensor matrix," D.R. Moreno, F. Pichler, A.A. Quesada(eds.), Computer Aided System Theory - EUROCAST 2005, Springer, Heidelberg, pp. 27-32.

[30] L. Kehong, T. Xiaodong, L. Guanjun, Z. Chenxu, "Sensor selection of helicopter transmission systems based on physical model and sensitivity analysis," Chinese Journal of Aeronautics, vol.27, pp.643-654, 2014

[31] S.D. Lira, V. Puig, J. Quevedo, A. Husar, "LPV observer design for PEM fuel cell system: Application to fault detection," Journal of Power Sources, vol.196, pp.4298-4305, 2011
[32] L. Mao, Jackson, L, "Selection of optimal sensors for predicting performance of polymer electrolyte membrane fuel cell," Journal of Power Sources, vol.328, pp.151-160, 2016.

[33] J.T. Pukrushpan, "Modeling and control of fuel cell systems and fuel processors," Doctoral dissertation, The University of Michigan, USA 2003.

[34] M.J.Khan, M.T. Iqbal, "Modeling and analysis of electrochemical, termal, and reactant flow dynamics for a PEM fuel cell system .”. Fuel Cells, vol. 5, pp463-475.

[35] S. Haji, "Analytical Modeling of PEM fuel cell i-V curve." Renewable Energy, vol. 36, pp. 451-458.

[36] M. Jouin, R. Gouriveau, D. Hissel, M.C. Pera, N. Zerhouni, "Degradations analysis and aging modeling for health assessment and prognostics of PEMFC. " Reliability Engineering and System Safety, vol.148, pp.78-95, 2016.

[37] J.M.L Canut, R.M. Abouatallah, D.A. Harrington, "Detection of membrane drying, fuel cell flooding, and anode catalyst poisoning on PEMFC stacks by electrochemical impedance spectroscopy," Journal of the Electrochemical Society, vol.153, pp.857-864, 2006.

[38] C.G. Chung, L. Kim, Y.W. Sung, J. Lee, J.S. Chung, "Degradation mechanism of electrocatalyst during long-term operation of PEMFC," International Journal of Hydrogen Energy, vol.34, pp.8974-8981, 2009.

[39] T. Ous, C. Arcoumanis, "Degradation aspects of water formation and transport in proton exchange membrane fuel cell: A review," Journal of Power Sources, vol.240, pp.558-582, 2013.

[40] FCLAB research. "IEEE PHM data challenge 2014," 2014. http://eng.fclab.fr/ieee-phm-2014-data-challenge/

[41] Y. Vural, D.B. Ingham, M. Pourkashanian, "Performance prediction of a proton exchange membrane fuel cell using the ANFIS model," International Journal of Hydrogen Energy, vol.34, pp.9181-9187, 2009.

[42] S. Becker, V. Karri, "Predictive models for PEM-electrolyzer performance using adaptive neuro-fuzzy inference systems," International Journal of Hydrogen Energy, vol.35, pp.9963-9972, 2010.

[43] R.E. Silva, R. Gouriveau, S. Jemei, D. Hissel, L. Boulon, K. Agbossou, N.Y. Steiner, "Proton exchange membrane fuel cell degradation prediction based on adaptive neuro-fuzzy inference systems, " International Journal of Hydrogen Energy, vol.39, pp.1-17, 2014.

[44] H. Liu, H.Q. Tian, D.F. Pan, Y.F. Li, "Forecasting models for wind speed using wavelet, wavelet packet, time series and artificial neural networks," Applied Energy, vol.107, pp.191-208, 2013.

[45] Z. Du, X. Jin, Y. Yang, "Fault diagnosis for temperature, flow rate and pressure sensors in VAV system using wavelet neural network," Applied Energy, vol.86, pp.1624-1631, 2009.

[46] E. Frappe, A.D. Bernardinis, O. Bethoux, D. Candusso, F. Harel, C. Marchand, G. Coquery, "PEM fuel cell fault detection and identification using differential method: simulation and experimental validation," The European Physical Journal Applied Physics, vol.54, pp.1-11, 2001.

[47] Z. Li, R. Outbib, D. Hissel, S. Giurgea, "Online diagnosis of PEMFC by analyzing individual cell voltages," European Control Conference, Zurich, Switzerland, 2013.

[48] Z. Li, R. Outbib, D. Hissel, S. Giurgea. Data-driven diagnosis of PEM fuel cell: A comparative study," Control Engineering Practice, vol.28, pp.1-12, 2014.

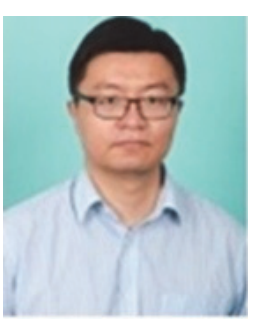

Lei Mao received the $\mathrm{BSc}, \mathrm{MSc}$ and $\mathrm{PhD}$ degrees from Hefei University of Technology, China, The University of Science and Technology of China, China, and The University of Edinburgh, UK, in 2004, 2007, and 2012, respectively.

From 2012 to 2013, he was a research associate with University of Portsmouth, UK. From 2013, he held a research associate position with Department of Aeronautical and Automotive Engineering, Loughborough University, UK. His research interests include system reliability analysis, development of intelligent health management system, fault diagnostic and prognostic techniques. 


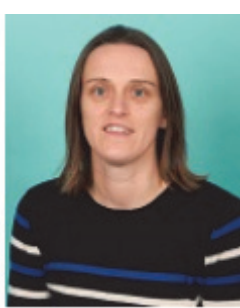

Lisa Jackson received the $\mathrm{PhD}$ degree from Loughborough University, UK in 2000.

From 2004, she became a member of academic staff in Department of Aeronautical and Automotive Engineering, Loughborough University. From 2010, she was promoted to senior lecturer with the Department of Aeronautical and Automotive Engineering, Loughborough University, UK. Her research has focused on multi-objective optimization applied to safety system design, fault diagnostic methods, enhancements in reliability assessment, and optimization techniques for demand modelling and resource allocation.

Dr. Jackson has gained funding from EPSRC, ESRC and a variety of industries. She is currently working on the Robust Lifecycle Design and Health Monitoring for Fuel-Cell Extended Performance (EP/K02101X/1) and the Adaptive Informatics for Intelligent Manufacturing (EP/K014137/1).

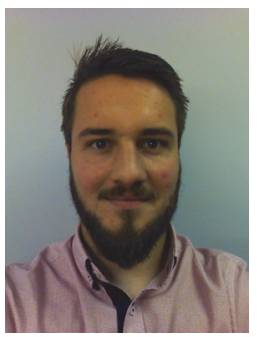

systems.

Ben Davies was born in London, UK. He received the MSc degree in Aeronautical Engineering from Loughborough University, UK in 2013.

From 2013, he worked as a PhD researcher at Department of Aeronautical and Automotive Engineering, Loughborough University, UK. His research is mainly focused on the online diagnostic systems for fuel cells, as well as practical degradation testing for PEMFC 